\title{
Bad Governance and Failure of Development Progress in Egypt
}

\section{Causes, Consequences and Remedies}

\author{
Dr. Wael Omran Aly \\ $\mathrm{PhD}$. of public administration \\ High institute of computer sciences and information systems \\ New Cairo Academy- Egypt \\ E. mail: wael.omran@ymail.com \\ Mob: 0202/1222479575
}

Accepted: October 09, 2013

doi:10.5296/ jpag.v3i4.4340 URL: http://dx.doi.org/10.5296/ jpag.v3i4.4340

\begin{abstract}
This article argues that the accumulative bad governance in Egypt over three decades and its failure to realize the intended development for the people represents one of the main reasons why people revolted. Bad governance contributed to the fall of Mubarak regime in three fundamental ways: first, it created the conditions (such as rampant corruption, violation of human rights and absence of rule of law) that served to inspire public action against the rulers; second, it led to the breakdown of core elements critical for regime stability (within the bureaucracy and the judiciary for example) and third it catalyzed the middle-class who played a key role in agitating for the uprisings via Face-book and other social media. However, in exposing the dynamics of bad governance in Egypt, this article suggests that the problem is not only one of governance gone badly; but also the lack of comprehensive 'good governance' paradigm capable to overcome bad governance aspects. So, by focusing only on institutional reform, the good governance paradigm did not capture the way in which actors, processes and values become diffuse across the state-society divide.

A relational governance approach would be more analytically useful in capturing and engaging with some of these dynamics. Whereby, through partnership adoption-which is one of good governance pillars- decentralization of powers and responsibilities from a higher to a lower level of government should been held out as an answer to a multitude of diverse political challenges to realize the desired societal development. It is often assumed that as an organizing principle, decentralization reduces corruption by bringing government closer to
\end{abstract}


the people (citizens' empowerment). Citizens are central to this thinking in terms of sensitizing them to public ethics. (Re)orienting public officials towards becoming reflective (responding) public officials according to new public management perspective (NPM) that may pave the way for effective development administration (DA) resurrection; which might be capable to translate people aspirations into actions; that could be more pertinent to recent revolutionary events in much of the Arab world countries as Egypt.

Keywords: bad governance, development administration, new public management.

\section{Overview}

The concept of good governance came to the fore in the 1990s against the backdrop of the failure of adjustment policies and with a view of developing a new recipe for enhancing the efficiency and capacity of governments to deliver. The World Bank, UNDP, as well as many other key international players, promoted the good governance paradigm as another side of the economic liberalization coin. While some considered it a recycled version of politics(UNESCAP, 2011), others argued that it presented a new perspective on development( OHCHR, 2007; PP.7-9), since it propagates principles such as accountability in societies suffering from the authoritarian corruption ( UNDP,1997; PP.17-19). While some definitions tended to limit the concept to the principles that make democracy function, for example creating representative and accountable government, building a strong and pluralistic civil society and supporting the rule of law and access to justice institutions (AUSAID ,2000); others, that highlighted responsive public administration and wider participation, were seen as real indicators of good governance (Graham, J. et al., 2003; PP.120-123).

Larry Diamond noted that most of good governance elements require a political will rather than material: Every government can create an independent administration, and every parliament can pass counter corruption commission and electoral laws giving citizens freedom of information and requiring that officials declare their assets These require political will, not economic development or high state capacity

(Diamond, L., 2008; P. 324).

Then, governance is more than a governmental activity; it is almost as a new social contract based on partnership between government, private sector and different civil society organizations; which entails better mobilizing for society's capabilities, and more rationality for public administration affairs. Whereas, governance embodies diversity, multitude, public accountability, respect of law and human rights; and also it promotes for visibility, integrity and people participation (Affandi, A. et al, 2008; PP.3-8).

As such, good governance signified not only the right of citizens to have transparent and accountable government, but also the necessity to capacitate public administration to implement public policies effectively (Diamond, L. et al., 2004; PP.7-27).

Though, in developing countries as Egypt, the public administration had to realize public 
policies; that yield the economic development for the grassroots in a context of good governance. But, in fact public administration in such countries suffers from many problems that labeled its management as conventional management.

Therefore, converting such conventional rigid public administration apparatus into development administration apparatus capable to maintain the good governance conditions necessary for the country development; must be one of the first priorities for the Egyptian government after the recent revolution of January 2011 and its consecutive revolutionary trends.

\section{2- Bad governance in Egypt: causes and scope}

The accumulation of several factors provoked such governance failure in Egypt. Such factors differ as some of them are political, economical, cultural social and others are institutional and organizational. We should note hereby that most of such bad governance factors emerge from the insidious corruption of former Egyptian regime; which represent one of the eminent factors of bad governance. Each of these factors of bad governance will be dealt with briefly below.

\subsection{Acute corruption}

The most popular and simplest definition of corruption is that it is the abuse of public power for private benefit. This is the definition used by the World Bank (World Bank, 2012). From this definition it should not be concluded that corruption cannot exist within private sector activities. Especially in large private enterprises, this phenomenon clearly exists, as for and so on. In fact, in many countries some of the proceeds of corruption go to finance the political parties.

Not all acts of corruption result in the payment of bribes. For example, a public employee who claims to be sick but goes on vacation is abusing his public position for personal use. Hereby, he is engaging in an act of corruption even though no bribe is paid. Or the president of a country who has an airport built in his small hometown is also engaging in an act of corruption that does not involve the payment of a bribe (Tanzi, V., 1998; P.8). It is important to distinguish bribes from gifts. In many instances, bribes can be disguised as gifts. A bribe implies reciprocity while a gift should not (Ibid; P.9). However, even though the distinction is fundamental, it is at times difficult to make. At what point does a gift become a bribe? Does the distinction depend on the size of the gift? What about cultural differences that can explain different sizes of gifts? What if a large gift is not given to the person who provides the favor but to a relative of that person? Does the distinction depend on whether the gift is given in broad daylight, for everyone to see, or privately? In any case, this indicates that the identification of a bribe may not always be simple; example in procurement or even in hiring. It also exists in private activities regulated by the government (Tanzi, V., 1995; PP.161-180).

In several cases of corruption, the abuse of public power is not necessarily for one's private benefit but it can be for the benefit of one's party, class, tribe, friends, family, and so on. In fact, in many countries some of the proceeds of corruption go to finance the political parties (Roberto, M. et al, 2012; PP. 430-432). 
Generally, acts of corruption can be classified in different categories. Some of these categories are mentioned below without specifically commenting on them or even defining them. Thus, corruption can be (Tanzi, V., 1998; P.10):

1) Bureaucratic (or "petty"), i.e. corruption by the bureaucracy or by the political leadership (or "grand"); (2) Cost-reducing (to the briber) or benefit-enhancing; (3) Briber-initiated;

(4) Coercive or collusive; (5) Centralized or decentralized; (6) Predictable or arbitrary;

(7) Involving cash payments or not.

Undoubtedly, other classifications could be added to this list.

Hereby in Egypt the pervasiveness of corruption catalyzed the revolution; whereas Egypt had been ranked among the most corrupted countries- rank115 out of 163 countries- in the world according to corruption index issued in 2012 by the international transparency organization (transparency organization, 2012).

The causes of Egyptian corruption appear in several ways (Fawazy. S, 2012; P.55): First, the absence of accountability mechanisms. Second, the lack of effective institutional control, the alliance between business and the ruling powers was predatory and hence became a source of deep resentment within the public. Finally, corruption had a spillover effect into wider society and became part of the social fabric, lack of transparency in rules, laws and processes, decline of public sector wages level and examples by the leadership. Each of these dimensions of corruption in relation to the uprisings will be dealt with briefly below.

\subsubsection{Corruption and absence of accountability}

In theory, accountability is a cornerstone of democratic governance and it simply means that those who hold public office must give account for their actions. There are two types of public accountability in a democratic state; vertical and horizontal. Vertical accountability refers to the power of citizens to hold those in powers accountable through, for example setting up anticorruption and human rights non-governmental organizations (NGOs), publishing corruption stories in the media and voting in public elections. Horizontal accountability embodies a wide range of institutions that oblige the accountability of officeholders to one another; 'this constraints executive power and so helps protect constitutionalism' (Diamond, L., 1999; P.10). Some examples of horizontally accountable institutions are financial control bodies, the judiciary and parliament. In a democratic society, both types of accountability complement each other. In authoritarian regimes vertical accountability is undermined by rigging elections, repressing civil society organizations and cracking down on free media. Also, the authoritarian regimes always outwardly maintain the structures of horizontal accountability but without any substance or effect. For example, a crippled parliament not only prevents genuine accountability, but also legitimizes apathetic, irresponsive and corrupt government (Mahmoud, H., 2011; PP.10-11).

In Egypt, both vertical and horizontal accountability have been most inept. Vertically, the depoliticisation of civil society crippled civic associations' ability to act as a watchdog and demand government accountability (Fawazy, S., 2012; P.56); while the co-option of the media also obstructed its ability to hold the government accountable. Horizontally, one of the most 
important forums of holding the government accountable, the parliament, had been dominated by ruling party members and government sympathizers (Soot, M., et al., 2012; PP 83-93).

\subsubsection{The lack of effective institutional control}

The existence of these controls reflects to a large extent the attitude of the political body toward this problem. Generally, the most effective controls are those that exist inside institutions. This is really the first line of defense. Honest and effective supervisors, good auditing offices, and clear rules on ethical behavior should be able to discourage or discover corrupt activities. Good and transparent procedures should make it easier for these offices to exercise their controls. Supervisors should be able to monitor the activities of their subordinates. These characteristics vary from country to country. In some these checks are almost non-existent so that corruption is mostly discovered by chance or through the reporting by outsiders, including the media (Langseth, P. et al., 1997; PP. 90-92).

\subsubsection{Predatory coalition between the ruling party and business}

The convergence of financial interests of actors who were simultaneously in government/ruling party and the business sector opened the door for the emergence and consolidation of highly predatory coalitions. In 2002 alone, as many as 48 high-ranking officials including former cabinet ministers, provincial governors and members of parliament were convicted of influence peddling, favoritism, profiteering and embezzlement (Al-Ahram, 2004) .These included a former minister of finance, a former head of the Customs Authority, a former governor of Giza governorate, as well as some prominent bankers for corruption related to unpaid loans; newspapers and lay people spoke about other cases where no official action was taken.

The Ministry of Administrative Development's role in fighting corruption was only cosmetic, since the relationship between politics and business remained beyond scrutiny. New laws to curb corruption (i.e. the customs and taxes laws and by-laws) existed only on paper and when, in 2007, the Minister of Administrative Reform established the Committee of Transparency and Integrity, its role was strictly consultative: proposing a national strategy and appropriate legal and administrative frameworks to combat corruption and help people to get their complaints heard and properly addressed (Fawazy, S., 2012; P.57). Four major governmental activities were the most associated with corruption: government purchases, customs and taxes, job recruitment and local administration. (Committee of Egyptian administrative development minister, 2007; PP.2-9)

\subsubsection{Lack of transparency of rules, laws and processes}

In Egypt, the lack of transparency in rules, laws, and processes creates a fertile ground for corruption. Rules are often confusing, the documents specifying them are not publicly available, and at times, the rules are changed without properly publicized announcements. Laws or regulations are written in a way that only trained lawyers can understand and are often conceptually and not just linguistically opaque about important aspects thus leaving grounds for different interpretations. Processes or procedures on policy matters and other 
actions, as for example for competitions for public projects, are equally opaque so that, at times it is difficult to understand the process that was followed before a decision was reached (Mahmoud, H., 2011; PP.14-15).

\subsubsection{Level of public sector wages}

Over the years many observers have speculated that the wages paid to civil servants are important in determining the degree of corruption. For example, Lindbeck attributes the low corruption in Sweden in this century partly to the fact that at the turn of the century, high-level administrators earned 12-15 times the salary of an average industrial worker (Lindbeck, A.,1998; P.65).

Thus, in Egypt one can speculate that there may be corruption due to greed and corruption due to need. There is a tradeoff between the level of corruption and the level of wages. The higher the wage level, the lower is corruption (The report of corruption conditions in Egypt, 2007; P.22).

\subsubsection{Examples by the leadership}

A final contributing factor is the example provided by the leadership. When the top political leaders do not provide the right example, either because they engage in acts of corruption or, as is more often the case, because they condone such acts on the part of relatives, friends, or political associates, it cannot be expected that the employees in the public administration will behave differently. The same argument applies within particular institutions such as tax administration, customs, public enterprises, and so on. These institutions cannot be expected to be corruption-free if their heads do not provide the best examples of honesty (Werner, N., et al., 2012; PP.96-100).

In Egypt, the leadership has been somewhat indifferent to this problem; as the former President Mubarak refused to fire ministers widely reputed to be corrupt. And also many ministers that were accused of corruption were simply moved to head another ministry or higher governmental positions. Examples such as these do not help create the climate that would lead to a corruption-free society.

\subsection{Deplorable bureaucracy}

The quality of the bureaucracy varies greatly among countries. In some, public sector jobs give a lot of prestige and status; in others, much less so. Many factors contribute to that quality. Many years ago Max Weber (1947), the outstanding German sociologist, described what should be the characteristics of an ideal bureaucracy. He was aware that most bureaucracies are not ideal. Tradition and the effect that it has on the pride that individuals have in working for the government may explain why, some bureaucracies are much more efficient and much less vulnerable to corruption than others (Vito, T., 1998; P16). Rauch and Evans have gathered information on the degree to which civil servants' recruitment and promotions are merit-based for developing countries. Their results indicate that the less are recruitment and promotion based on merit, the higher is the extent of corruption (Rauch et al., 1997; PP.98-100). Absence of politically motivated hiring, patronage, and nepotism, and 
clear rules on promotions and hiring, in addition to some of the factors discussed separately below all contribute to the quality of a bureaucracy. The incentive structure plus tradition go a long way to explain why some bureaucracies are much less corrupt than others (Kaufmann, D., et al., 2006; PP. 2-8).

Historically, the bureaucracy served as an indispensable arm of the Egyptian regime. It ensured stability and order, produced and distributed public goods, punished the enemies of the regime and maintained its grip on power through rigging elections. Mubarak, like his predecessors, expanded bureaucracy, consolidated its power, covered up its human rights violations and distributed benefits to those who occupied key positions in the state apparatus. The amalgamation of the NDP (the ruler party: the national democratic party) and public bureaucracy resulted in not only a 'partial public service' but was also deployed to prop up the regime. The corruption that permeated the bureaucracy had a spillover effect on wider society (Ayoubi, N., 1982; PP.295-297). The inability of public bureaucracy to perform its duties coincided with a noticeable deterioration in the performance of non-state actors and the private sector. This supports Fukuyama's argument that there is a direct relationship between governance and public culture, in that the accountable and transparent government helps disseminate positive public values in other society organizations (Fukuyama, F., 2004; PP.39-41). The bureaucracy maintained its supremacy in licensing, establishing and monitoring private enterprises, and NGOs. In such a context, it was not possible to establish partnerships between government, private sector and civil society that could create developmental coalitions (Hyden, G., 1997; P.30).

A government report revealed that consumer trust in economic performance fell under the equilibrium index during the last few months before the January 25th revolution: reaching its lowest point, 72.6, 72.3 and 72.9 in August, September and October 2010, consecutively. Indexes over 100 correspond to countries where a majority of people trust economic performance, while an index under 100 corresponds to countries where a majority of people have less trust in economic performance (IDSC, 2011).

In light of the above, one can say that Egypt introduced a good example of 'apathetic bureaucracy'. In a survey about bureaucracy, the results showed that decentralization and delegation of authority are absent. The authoritarian political regime had deliberately created a highly centralized public bureaucracy (Yassin, E., 1994; PP.65-106); where citizens faced time-consuming processes in public organizations due to the top-down bureaucratic system (Al Masry.1997; PP.16-17). In the end, the bureaucracy came to symbolize the decay of the regime and its disconnect with the people, and was targeted as such in the torching of buildings by the public, along with the State Security Investigations apparatus (SSI) premises.

\subsection{Rule of law and administration of justice}

The rule of law is a fundamental pillar of democratic governance. The absence of the rule of law was one of the main grievances around which people catalyzed and mobilized prior to and at the outset of the revolution. Furthermore, a movement within the judges, who were supposed to represent one of the cornerstones of regime stability had turned against it and joined the ranks of the opposition. Hence, the conditions of injustice created a fertile ground 
for mobilization, while the resistance of the judges to cooption and their radicalization strengthened the growing opposition's contestation of regime legitimacy. The January 25th revolution and its consecutive revolutionary trends were a direct reaction towards the lack of justice and human rights violations. The widespread abuse of ordinary citizens' rights provided an environment conducive to wider public participation in anti-regime demonstrations (Mahmoud, H., 2011; P.20).

\subsection{Economical policies and trends}

Among the economic changes that have taken place in recent years, privatization is the one that has been more closely linked with corruption in Egypt. There is no question that public or state- owned enterprises have been a major source of corruption and especially of political corruption because, occasionally, they have been used to finance the activities of political parties and to provide jobs to the members of particular political groups; this was clearly the case in Italy and in many Latin American countries, and also in Egypt (Manzetti, L., et al , 2006; PP.131-135) (Bentze, J., 2012; PP. 168-175) (Boerner, K., et al., 2009; PP. 213-220).

Privatization of non-natural monopolies is a necessary step to reduce this form of corruption because it eliminates an instrument often used especially in political corruption. Unfortunately, the process of (ministers, high political officials) has the discretion to make the basic decisions while others (managers and other insiders) have information not available to outsiders so that they can use the process to benefit themselves (Report of corruption conditions in Egypt, 2007; PP.22-39).These problems have been observed and reported in all regions of the world, but the abuses appear to have been particularly significant in the transition economies as in the case of Egypt (Ibid, 2007; P.40). Whereby in the latter, terms such as asset stripping privatization have been used to describe the abuses associated with the transfer of state enterprises to private ownership with complete absence of visibility and accountability.

Thus, in Egypt as a clear aspect of fortune distribution unbalance; some individuals have become enormously rich because of these abuses. This, in turn, has made many citizens suspicious, or highly skeptical, about the virtues of a market economy (Mahmoud, H., 2011; P.22).

Thus, several arguments lead to the conclusion that the current interest in corruption may reflect an increase in the scope of the phenomenon over the years and not just a greater awareness of an age old problem.

\section{Consequences of bad governance}

Bad governance in Egypt had many negative aspects in the society. Some of them are economical and others are political, cultural and social.

\subsection{On the domestic economy and development progress:}

In the past couple years, several studies, using cross-section analysis and utilizing the available corruption indexes, have reported important quantitative results on the effects of bad governance on economic variables. These results suggest that corruption and bad 
governance has a negative impact on the rate of growth of countries. It has been found that bad governance reduces investment and, as a consequence, it reduces the rate of growth and development. Such reduction in investment is assumed to be caused by the higher costs and by the uncertainty that corruption creates. In this analysis, the reduction in the rate of growth is a direct consequence of the decline in the investment rate. In other words, the analysis is based on a production function that makes growth a function of investment (Maura, p., 1995; pp.681-690). Thus, the expenditures for education and health are reduced; as they don't lend themselves easily to corrupt practices, especially on the part of those who make budgetary decisions (Maura, P., 1997; pp. 230-231). Bad governance also increases public investment; because public investment projects lend themselves easily to manipulations by high level officials to get bribes; it also distorts the effects of industrial policy on investment (Tanzi, V. et al., 1997; p.131). It reduces also many economical realms such as: expenditures for operation and maintenance for reasons similar to those that reduce expenditure for education and health, the productivity of public investment and of a country's infrastructure, tax revenue mainly because of the impact that it has on the tax administration and on customs by reducing the ability of the government to carry out needed public expenditures and foreign direct investments because corruption has the same effect as a tax, and in fact it operates as a tax. Hence, less predictable is the level of corruption (the higher is its variance), the greater is the impact on foreign direct investment (Ibid, p.132).

\subsection{The spillover effect on political and social aspects of the society}

Bribery became systematically entwined in Egypt's daily life. People bribe public employees to get both legal and illegal services (Henien, F., 2007; PP.110-111). Although the circles of corruption had expanded, spilt over from state to society to represent almost a normative framework, by default, counter-coalitions emerged against corruption. There was a great uprising against regime policies across all the institutions that comprised the professional middle-class. Indeed, the relationship between financial corruption and human rights violations was one of the main catalysts that inspired the January 25 th revolution. It was not only the poor who suffered from corruption but the 'upwardly mobile professional classes' also (Fadel, M., 2011; PP.3-7). Furthermore, there seems to be a wide gap between the penalties specified in the laws and regulations and the penalties that are effectively imposed (Emilson, C., et al, 2007; PP. 79-87) (Marquette, H., et al, 2012; pp. 11-19).

Generally, effective penalties tend to be more lenient than the statutory ones. The administrative procedures followed before a public employee is punished for acts of corruption are slow and cumbersome. Often legal, political, or administrative impediments prevent the full or quick application of the penalties. The potential accusers are often reluctant to come forward and to spend the time and effort to go through the full process required to punish someone. Also, when corruption is widespread, the costs to the accusers in terms of social capital, such as lost friends, can be high (Batory, A., 2012; PP.76-82).

Furthermore, the judges who will impose the penalties may themselves be accessible to corruption or may have political biases, so that they may be bought by the accused or may put obstacles to the proceedings. All these factors limit the role that penalties actually play in 


\section{Macrothink}

Journal of Public Administration and Governance ISSN 2161-7104 2013, Vol. 3, No. 4

Egypt, especially when corruption is partly politically motivated. This attitude brings toleration for small acts of corruption that can in time encourage bigger acts (Fawazy, S., 2012; p. 58).

\section{The fight against bad governance and the role of the state}

\section{1 good governance indices:}

Governance is considered as the traditions and institutions by which authority in a country is exercised for the common good. This includes: (Kaufmann, D., 2000; PP.16-19)

- The process by which those in authority are selected, monitored, and replaced (the political dimension).

- The government's capacity to effectively manage its resources and implement sound policies (the economic dimension).

- The respect of citizens and the state for the country's institutions (the institutional respect dimension). At the World Bank, in order to more closely define and measure governance, some aggregate Governance Indicators have been constructed, which now cover more than 200 countries, based on more than 350 variables, obtained from dozens of institutions worldwide, including the Survey. The Governance Indicators capture six key dimensions of institutional quality or governance, and measure, through two indicators each, the political, economic, and institutional dimensions of governance described above.

The following six dimensions are measured: (Kaufmann, D., 2000; P.20)

(Bishara, N., 2011, PP.227-237)

1. Voice and accountability — measuring political, civil and human rights.

2. Political instability and violence-measuring the likelihood of violent threats to, or changes in, government, including terrorism.

3. Government effectiveness-measuring the competence of the bureaucracy and the quality of public service delivery.

4. Regulatory burden-measuring the incidence of market-unfriendly policies.

5. Rule of law-measuring the quality of contract enforcement, the police, and the courts, as well as the likelihood of crime and violence.

6. Control of corruption-measuring the exercise of public power for private gain, including both petty and grand corruption, and state capture.

It is generally accepted by multilateral and bilateral donor agencies that corruption is widely recognized as a public wrong, wastes limited resources and donor funds, disadvantages the poor, inhibits democratization and highlights private benefit over the public interest. The prevailing orthodoxy is that corruption is one of the major impediments to human development. That it must be addressed is not challenged - and evidence of challenge to corruption is also often seen as evidence of a country's commitment to developmental 
progress. The core issue raised in this special issue is to ask whether there are alternative approaches that would also foster 'a culture of corruption rejection', whereby three of them are addressed here ( Alan , 2012; PP. 129-130).

The first approach has been to promote governance arrangements that are assumed to support or facilitate anticorruption initiatives. Thus, the United Nations Development Program (UNDP) has argued that mainstreaming of anti-corruption is most likely to be successful if it is closely integrated in other key functional service areas of democratic governance, such as local governance, public administrative reform and economic governance, access to justice, parliamentary strengthening, electoral processes, independent media development, e-governance, civic engagement (including political parties), and human rights'(UNDP, 2008; PP. 28-29). In other words, anti-corruption may take place in the context of, and benefit from, wider democratic governance reforms. The assumption that decentralization will reduce corruption is without foundation. We find that decentralization increases corruption significantly; that this increase persists during the medium term. However, we also observe that over a period of time there is reduction in (Asthana, A., 2012; PP. 27-37).

The second approach recognizes the failings of existing repressive institutions, particularly law enforcement agencies which were seen by many donors as corrupt or inefficient (and often both). They have focused, and continue to focus, on the establishment of the dedicated agency - the anti-corruption agency (ACA or anti-corruption commission). Nevertheless, the effectiveness of ACAs to deliver an anti-corruption agenda has been under review from both academic and practitioner perspectives; a 2005 UNDP report on institutional anti-corruption arrangements noted that 'several countries have opted for or are currently considering creating an independent commission or agency charged with the overall responsibility of combating corruption.

However, the creation of such an institution is not a panacea to the scourge of corruption. There are actually very few examples of successful independent anti-corruption commissions/agencies' (Doig, A., 2006; PP. 163-172) (Doig, A., 2007; PP. 251-259) (UNDP. 2005; P.5.) (OSCE, 2004; PP.11-12).

A distinguish article on the Indonesian Komisi Pemberantasan Korupsi (KPK) reports that its success was achieved against the odds of low governance indicators and entrenched continuing corruption. The effectiveness of its continuing work could not rely solely on the efforts of the agency itself but would, she argues, require 'alliances with reform-friendly government agencies and leverage beyond the support of civil society; in order to reach a critical mass where corruption becomes the exception rather than the rule. Sustainable progress will depend particularly on increased cooperation from and with the other law enforcement (Schütte, S., 2012; PP.38-48).

The third approach seeks to embed anti-corruption initiatives within delivery of projects and programs. But, as Vian et al. argue, controlling corruption is a critical component of governance and is essential to achieve health sector goals of improved quality of care and equity in access and outcomes. Government, providers, and citizens and service users each 
have a role to play in promoting good governance for better health. Key to success is unlocking the incentives that enable and motivate health system actors to fulfill their roles and adapting strategies to work within and overcome institutional constraints (Vian, T. et al., 2012; P.61).

They do note that, while corruption-reduction interventions are required in the areas of administrative oversight, transparency initiatives and civil society participation, and health reforms to change incentives, controlling corruption also requires changes in institutions, attitudes and behavior.

The three approaches do not provide unequivocal evidence that they have or will address corruption effectively and on a sustained basis. All three note the importance of the operating environment or governance arrangements; they also implicitly or explicitly point to the conduct of the public officials who are responsible for delivering both in such a way that supports or facilitates the work of agencies, projects and programs. It must be obvious to all those involved in anti-corruption work that minimization of potential or actual engagement by public officials in corrupt activity would have significant implications for addressing corruption, as well as wider governance issues (Doig, A., 2012; P.131).

Hence, integration among such three previous approaches is a must to preclude bad governance manifestations in different countries including Egypt. As the absence of suitable arrangements on one or more of these following criteria will jeopardize prospects for transformative change to good governance :( Luna, M., 2002; PP. 1-7)

- Political commitment for governance reforming.

- Meaningful participatory approaches that are inclusive and account for power differentials between nation, states, non-state actors and other groups (stakeholders) in society such as governmental organizations, private sector and non-governmental organizations.

- $\quad$ Appropriate and stable levels of funding.

- Appropriate authority and efficiency to public administration apparatus; by adopting reinventing principles to transform the conventional public administration into new public management (entrepreneur government); characterizes with flexibility and small size, sensitive structure adaptive to any environmental variations and capable to respond effectively to people needs.

- Appropriate capacity to address compliance and implementation.

- Effective adaptive approaches that could include sunset clauses and scheduled re-chartering moments in agreements, dynamic criteria to all selection and decision-making mechanisms to reflect changes in natural and social systems, and network approaches.

- Accountability: strong accountability and transparency safeguards.

- $\quad$ Responding to people needs within a specific time limitation. 
- Enhancing equity and inclusiveness among diverse citizens in the society.

- Good governance must strive to realize public consent among different citizens in the society yields to sustainable development.

\subsection{Comprehensive strategic framework for good governance in Egypt.}

According to previous analysis, taking into consideration the Egyptian case after the recent revolution of 25 January 2011 and its revolutionary waves as 30 June 2013 uprising; we suggest some pivotal pillars for governmental reforming needed to realize good governance in Egypt. Such pillars can be classified into short-run pillars and long-run pillars. The integration between such pillars is a must; to enhance good governance manifestation in the country.

\subsubsection{Short-run pillars:}

There are some immediate anti-corruption decisions that can be taken by the cabinet and the ministers to enhance good governance; such decisions don't need further law issuing or deep restructuring. They aim to realize the following good governance indices:

- Transparency: the governmental agency had to disclose their decisions to publics whether by using the electronic interfaces (E. governments) or by using internal billboards and different media means as newspapers and specialized reviews. Thereby, hygiene anticorruption environment can be created as the visibility stretches all through the governmental apparatus. Then, the negative societal whistle-blowing will vanish as the corrupted person will be nailed. So, effective transparency encumbers the corruption growth and contributes to the social and political stability prevalence (Aysan, A. et al 2007; PP. 345-355) (Kaufmann, D., 2000; pp.31-35).

- Partnership and decentralization:

Partners in any community entail government, private sector and non-governmental organization. Clearly, the citizen is the main component for all them; thereby various government agencies had to let all such societal partners participate at public policy formulation. Such partnership contradicted individualism; by ensuring the public interest realization especially those of marginal people. Individualism and centralization in public decisions making are the best friends to state tyranny; whereby they strive to realize the interest of a specific party or sect. Whereas, partnership and decentralization of public decisions respect diverse local communities aspirations; and respond effectively to various citizens needs. So, by such citizen empowerment the people satisfaction is guaranteed. Such people participation can be realized through different means: Hearing sessions; where the public authorities can use them -especially in local community- to discuss public problems and to know about people opinions in their policies whether they are old or new. Media means; whether they are written, hearing or visual are used to propose different public policies for public reforming program. Thereby, such public polices can be modified to meet citizens' expectations. Also, civil community organizations play a crucial role in arranging several workshops, forums and conferences that advocate people right in participation and 


\section{Macrothink}

enhance it (Ahn, M. et al., 2011; pp. 416-419).

- Accountability:

It means the ability to penalize immediately the responsible for any errors or mistakes nevertheless his status in job echelon or the society. Effective accountability entails three features (Mahmoud, H., 2012; pp.31-32):

* Swift justice: whereby slow justice is not pervasive.

* Disclosure enforcement: the penalties imposed on someone must be informed to all the society; so each one will hesitate before imitating such negative attitude.

* Equality and equity: the penalties must not differentiate between big employee or small one. Thus, people trust in government will be enhanced; so is the societal stability.

Thereby, the intended goal from the adoption of transparency, partnership and accountability in all public affairs is to enhance the efficiency and effectiveness of public policy; especially those related to public resource usage. Then, public goals will be realized effectively in a way that yields societal satisfaction; and maintain political, economical and social stability of the community.

\subsubsection{Moderated and long -run pillars:}

Realizing moderated and long-run goals will require issuing new laws and restructuring many public apparatus. Furthermore, we may need to establish new governmental entities. Such reforming policies must rely on public consent; whereby elected legislative authorities had to lead public campaigns for mobilizing public opinions around such policies.

We will shed light hereby on essential indices to realize good governance on moderated and long-run; as follows (see the figure below that illustrates such indices):

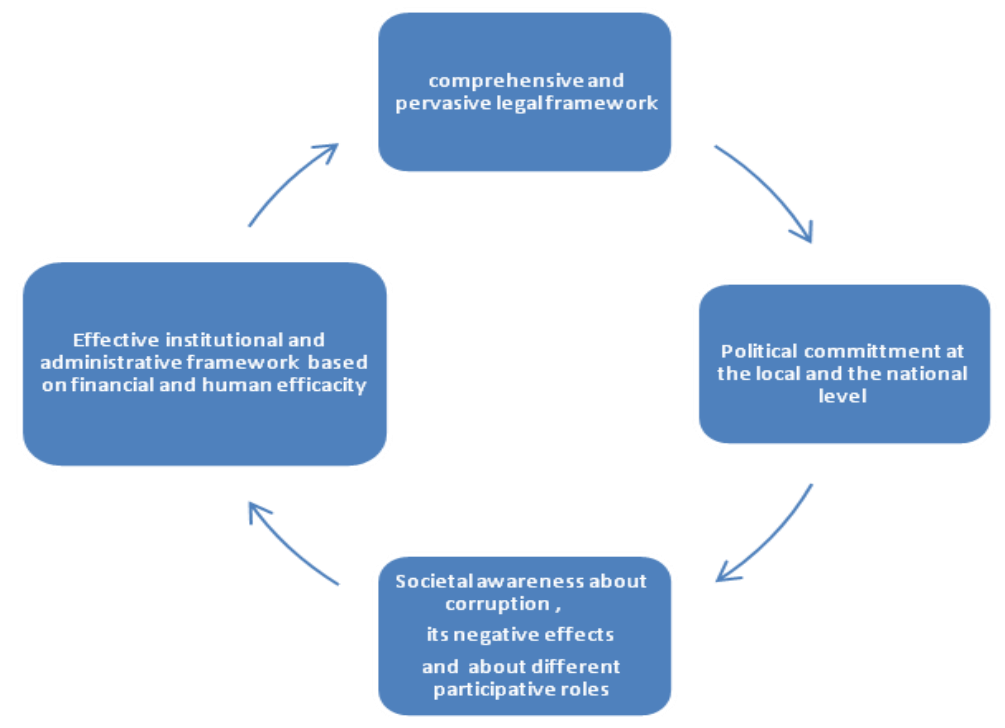

- Administrative reforming: 
Such pillar focus on public administration reforming derived from new public management (NPM) techniques; that may take place through procedures simplification, decisive job specification to avoid any duplication between government agenizes, e. government broaden applications; staffing and promotion systems reforming, wages and compensations systems reforming (A working paper around the feasibility of corruption, national commission establishment in Lebanon, 2011; pp. 20-24).

- Financial reforming:

It aims to create a public budget featured by visibility; clearly displayed and reliable for publics. Also, defects entailing private trustees and cash budgets had to be fixed; and so the public banks and corporations management (Anti- corruption national strategy (2008-2011), Jordanian kingdom, pp. 30-39).

\section{- Legislative and legal reforming:}

Legislations batch must be issued to fill the Egyptian legislative gap in many realms: information disclosure, witnesses' protection especially in corruption cases and organized crimes. Also, we had to reconsider the current laws through legal experts committees; to review them and avoid any legal contradictions that may impede its adaptation to Egyptian socio economical, political and cultural environment (Mahmoud, H., 2012; p. 33).

- Institutional reforming:

Detached the controlling apparatus from executive authority is a must. Thus, they can fulfill effectively their independent neutral task in controlling executive authority activities. Whereby, the majority of civilized modern countries- as Singapore, Indonesia and several Arab countries- established an independent anticorruption entity; that governs all the controlling institutions within such countries and coordinate among them. It is important to mention hereby; that UN anticorruption treaty assured on the necessity of such independent anticorruption apparatus establishment (Ibid; p.34).

- Societal and cultural conscious and training:

Various training programs had to be designed and executed to inform publics about anti-good governance elements such as corruption and its destructive effects; and also to let individuals and institutions aware about relevant anticorruption procedures. Different stakeholders in society such as families, media institutions, various governmental apparatus, religious and educational institutions, and civil society organizations must cooperate together and integrate their efforts. Then, they may be able to create the effective citizenship necessary for anticorruption fight; which will lead the country to good governance realization (Asthana, A., 2012; PP. 27-30).

\section{- Restructuring reforming:}

Economical and administrative reforming can't prosper without parallel political reforming may take place. Whereby, the political system must maintain a balanced relationship between the legislative, the executive and the judicial authorities. Such relationship had to ensure the 
independency among these authorities. Whereas for governmental media organizations; it had to enhance the detachment of ownership from management to preclude any potential political pressure. All such matters surely enhance the anticorruption efforts; which pave the way for good governance delivery (Aucoin, P., 2012; PP. 177-183).

- Global cooperation enhancement to good governance realization:

Enhancement of cooperation among national, regional and global anticorruption organizations; in order to realize the goals of US anticorruption treaty in criminals' delivery, information exchange, common inquiry, legal assistance for law pervasiveness, money laundry fight and properties retrieve. Then, the effective durability of such previous global cooperative; may yield the prospected good governance in Egypt.

Hence, we can recommend the following policies; to be followed by the Egyptian government to realize -as soon as possible- the intended aggregated good governance strategy:

- Due to the political jargon sprang in Egypt after 2011 and 30 June 2013 uprisings; the existent political leadership would tend to realize good governance. Therefore, government must convey such thrust to different governmental units, and to cooperate with the legislative authority to issue laws that enhance decentralization, people participation and corruption elimination.

- Energize the issuing of legislations and laws necessary to assure the realization of transparency, accountability and participation. Whereby, such laws can pertain the disclosure and information exchange law, anti-information crime law, civil service law, anti- organized crime law, activation of money laundry law, witnesses and corruption informers' protection law.

- Fill the gaps through which corruption may take place by separating between services providers and clients, simplifying the administrative procedures, and provide necessary manuals for various managerial procedures and its costs, enhancing e. government applications to facilitate citizens' procurement for various services, and to energize data and information flow among different users.

- It is important to create an effective system to citizens' relation management (CRM); to receive their complaints and resolve them. Thus, an ombudsman existence is a must to address such people complaints; whether they are personal or related to corruption events. It is important to mention that some criteria must exist to enhance the ombudsman's effectiveness. First, the ombudsman must have an independent entity; apart from the government. Thus, he should have comprehensive, independent and efficient organizational structure; that governs his activities to realize his valuable mission in revealing justice and equity among people. Second, he must have easy visible access to all necessary data and information; that he needs to fulfill his tasks. Third, remedies procedures taken by the ombudsman must respond to citizens' needs and resolve their problem; within a specific period of time known to the complainer. Finally, all the governmental and non-governmental apparatus had to submit to the ombudsman's decisions. Thus, the legislative authority must 
issue laws; to identify the nature of interrelations between various government agenizes and the ombudsman. So, different state apparatus had to positively respond to ombudsman's remedies decisions.

- It is important to create a societal culture that embraces citizens' empowerment. Whereby, training programs are designed and implemented to inform citizens about the corruption and its effects, and their rights to control and account public services performance. The government must lead such programs; whereas, the families, civil society organizations, education institutions and mass communication and media agencies had to play integrated decisive roles to enhance such programs. Then, all such efforts will yield effective citizenship necessary for corruption preclusion; which enhance surely good governance realization.

- The government had to catalyze the implementation of civil services reforming programs. Such programs must rely on new public management principles (NPM); such as:

1) restructuring the conventional huge rigid apparatus into small size flexible effective one; free of any duplication or overlapping; 2) reengineering the current administrative process to facilitate service procurement procedures and to enhance value- added activities. So, the quality is ensured; 3) adoption of human resources management systems to surrogate conventional personal management programs; 4) adjustment of staffing systems and training sessions to enhance job effectiveness as well as employees' satisfaction. So, the right person will fill into the right post; 5) redesign the wages systems and employees fringe benefits (healthcare insurance, social incentives...) to realize employees' financial satisfaction;

6) imposing an effective code of ethics to govern employees' behavior is a must; consistent with reinforcement procedures to ensure its application; 7) assuring the propagation of governmental information, rules and procedures; whereby, the majority of government agencies still use conventional red tapes and ask for unneeded document.

- Adoption of management by results as an adequate controlling method instead of traditional stages of executive control.

- Initiating of a central anti- corruption commission that enhances the cooperation and coordination among various controlling apparatus (administrative control agency, central apparatus for accountability...). Such commission had to lead aggregated anti- corruption campaigns; by setting appropriate strategies and policies necessary for that; in accordance with different stakeholders in the society (private sector, government agencies, civil society organizations, various people assemblies).

- Reactivation of integrity and transparency committee; which had been assembled before in 2007 by the minister of administrative development. Such committee must work under the umbrella of the potential anti- corruption commission; it is pertinent to Set the appropriate national indicators and criteria for corruption measuring and evaluation; and to interact with international specialized organizations to ensure the indicators' accuracy; and to Detect various administrative corruption cases and to monitor governmental agencies anticorruption performance. 


\section{Conclusion:}

We note after the previous analysis that there are diverse causes for bad governance and economical decay in Egypt; acute corruption is the most prominent among them. It reveals in Egypt due to the legal, political, social, economical, administrative and cultural context deterioration.

The realization of good governance in Egypt necessitates the adoption of various reforming indices that yields good governance; such indices are: people participation, law rules pervasiveness, accountability, transparency, anti-corruption procedures, responsiveness, public consent, equity and equality, and government agencies effective management (new public management principles adoption).

Hence, Egypt strategy to overcome bad governance should rely on broad applications of good governance indices; which can be realized by adopting some reforming pillars, whether on the short or long run. On the short run, the government can enhance participation, transparency and accountability; which represent some preventive interference from corruption dispersion. Such reforming indices don't need further law issuing or numerous structural changes; All what they need pervasive decisions by the concerning ministers. Whereas, on the moderated and long run government had to adopt different reforming dimensions to impede corruption; and to set various plans and policies for its implementation. Such reforming dimensions are: administrative reform, financial reform, institutional reform, training and societal culture reform, restructuring reform and enhancement of international cooperation for anti-corruption.

We assure hereby that the political commitment for reforming is a must; whereby no reforming efforts can success without the political leadership support and people awareness about the importance of reform. The government had to acquire also the necessary financial and technical resources to enhance their reforming program. It can procure such various resources by local funding or by foreign international grants and donations programs.

\section{References}

- A working paper around the feasibility of corruption national commission establishment in Lebanon, Lebanese transparency assembly, 2011.

- Affandi, A. Hussein, Non- government organizations and governance, literature review from economical, political and administrative perspective, Cairo University: faculty of economy and political sciences, economical and financial research center, 2008.

- Agnes Batory, Why do anti-corruption laws fail in Central Eastern Europe? A target compliance perspective, Regulation \& Governance journal, vol. 6, 2012.

- Ahmet Faruk Aysan \& others, Governance Institutions and Private Investment, An Application to the Middle East and North Africa, The Developing Economies review, Vol. 3, September 2007. 


\section{Macrothink}

Journal of Public Administration and Governance ISSN 2161-7104 2013, Vol. 3, No. 4

- Al Masry, A., The Basic Foundations of the Performance of Public Employee, Al Adara, vol. 29, no.3, 1997.

- Al-Ahram Weekly, Catching Up with High profile Corruption, 10 March 2004.

- Asthana N. Anand, Decentralization and corruption revisited: evidence from a natural experiment, Public Administration and Development, 32(1), 2012.

- AUSAID, Good Governance, Guiding Principles for Implementation, 2000, www.ausaid.gov.au/publications/pdf/good_governance.pdf (accessed 2 November 2011).

- Ayoubi, N., 'Bureaucratic Inflation and Administrative Inefficiency, the Deadlock in Egyptian Administration', Middle East Studies, 1982.

- Daniel Kaufmann \& Others, Measuring Governance, Corruption, and State Capture: How Firms and Bureaucrats Shape the Business Environment in Transition Economies, World Bank institute, April 2000.

- Daniel Kaufmann, Myths and Realities of Governance and Corruption, World Bank institute, 2006.

- David M. Luna, Anti- corruption and integrity enhancement: Mutual responsibility relying on transparency and prevention, paper presented into international institution of public ethics (IIPE) conference, Australia, October 2002.

- Diamond, L., The Spirit of Democracy: The Struggle to Build Free Societies Throughout the World, New York: Times Books, 2008.

- Diamond, L. and Morlino, L., The Quality of Democracy, CDDRL Working Paper 20, September 2004.

- Diamond, L., Developing Democracy towards Consolidation, Maryland: Johns Hopkins University Press, 1999.

- Doig A, Watt D, Williams R., Hands-on or hands-off? Anticorruption agencies in action, donor expectations, and a good enough reality, Public Administration and Development, vol. 26, no.2, 2006.

- Doig A, Watt D, Williams R., Why do developing country anticorruption commissions fail to deal with corruption? Understanding the three dilemmas of organizational development, performance expectation, and donor and government cycles, Public Administration and Development, vol. 27, no.3, 2007.

- Doig Alan, Conclusion To The Special Issue: Time To Consider Prevention As Well As Retribution?, public administration and development review, vol. 32, 2012.

- Egyptian Cabinet IDSC (Information and Decision Support Center) Egyptian Consumer's Trust Index in Economic Performance, 2011.

- Emil son C. D. Silva \& Others, Crime and Punishment and Corruption: Who Needs Untouchables? Journal of public economic theory, 9 (1), 2007. 


\section{Macrothink}

Journal of Public Administration and Governance ISSN 2161-7104 2013, Vol. 3, No. 4

- Fadel, M., Public Corruption and the Egyptian Revolution of January 25: Can Emerging International Anti Corruption Norms Assist Egypt Recover Misappropriated Public Funds?, Harvard International Law Journal Online vol. 52, 2011. www.harvardilj.org/online/ (accessed 5 October 2011)

- Fawzy Henien, S., Egypt: Bad Blood', in Jonathan Werve and Global Integrity (eds), The Corruption Notebooks, Washington DC: Global Integrity, 2007.

- Fukuyama, F., State Building, Governance and World Order in the Twenty First Century, London: Cornell University Press, 2004.

- Graham, J.; Amos, B., T. Principles of Good Governance in the 21st Century, Policy Brief 15.6, Institute on Governance, 2003.

- Heather Marquette, 'Finding God' Or 'Moral Disengagement' In the Fight against Corruption in Developing Countries: Evidence from India and Nigeria, Public Administration \& Development review, vol. 32, 2012.

- Http:// www.transparency.org/index/accessed 10/12/2012.

- Http://www.worldbank.org/ about governance/ accessed 5/12/2012.

- Hyden, G. 'Building Civil Society at the Turn of the Millennium', in John Burbidge (ed.), Beyond Prince and Merchant. Citizen Participation and the Rise of Civil Society, New York: Pact Publications, 1997.

- Jeanet Sinding Bentze, How Bad is Corruption? Cross-country Evidence of the Impact of Corruption on Economic Prosperity, Review of Development Economics, vol. 16, no. 1, 2012.

- Kira Boerner \& Christa Hainz, The political economy of corruption and the role of economic opportunities, Economics of Transition review, Volume 17, no.2, 2009.

- Langseth, Peter and Rick Stapenhurst, National Integrity System: Country Studies, Economic Development Institute of the World Bank, EDI Working Papers (Washington: The World Bank, 1997.

- Lindbeck, Assar, Swedish Lessons for Post-Socialist Countries, mimeo, 1998.

- Luigi Manzetti \& Carole J. Wilson, Corruption, Economic, Satisfaction, And Confidence in Government Evidence from Argentina, The Latin Americanist, Wiley press, 2006.

- Mari-Liis Soot \& Kadri Rootlau, Institutional Trust and Opinions of Corruption, public administration and development review, vol. 32, 2012.

- Mauro, Paolo, The Effects of Corruption on Growth, Investment, and Government Expenditure: A Cross-Country Analysis," in Kimberly Ann Elliott, editor, Corruption in the Global Economy, Washington: Institute for International Economics, 1997.

- Mauro, Paolo, "Corruption and Growth", The Quarterly Journal of Economics", August 1995. 
- Michael J. Ahn \& Stuart Bretschneider, Politics of E-Government: E-Government and the Political Control of Bureaucracy, Public Administration Review, May - June 2011.

- Norman D. Bishara, Governance and Corruption Constraints in the Middle East: Overcoming the Business Ethics Glass Ceiling, American Business Law Journal, Volume 48, Issue 2, 227-283, summer 2011.

- OHCHR Good Governance; Practices for the Protection of Human Rights, Geneva: Office of the United Nations High Commissioner for Human Rights, 2007.

- OSCE, Best Practices in Combating Corruption, Office of the Coordinator for Economic and Environmental Matters, Vienna, 2004.

- Paul D. Collins, Introduction to the Special Issue: The Global Anticorruption Discourse, Towards Integrity Management, Public Administration \& Development review, vol. 32, 2012.

- Peter Aucoin, New Political Governance in Westminster Systems: Impartial Public Administration and Management Performance at Risk, Governance, Vol. 25, No. 2, April 2012.

- Rauch and Evans, Bureaucratic Structure and Bureaucratic Performance in Less Developed Countries, mimeo, 1997.

- Roberto Martin, Victim or Victimizer: Firm Responses to Government Corruption, Journal of Management Studies, vol. 49, no. 2, March 2012.

- Sameh Fawzy, Accumulative Bad Governance, IDS Bulletin, Volume 43, Number 1, Blackwell Publishing, January 2012.

- Schütte S., against the odds: anti-corruption reform in Indonesia, Public Administration and Development, vol. 32, no.1, 2012.

- Tanzi, Vito and Hamid Davoodi, Corruption, Public Investment, and Growth, IMF Working Paper (Washington: International Monetary Fund), 1997.

- The report of corruption conditions in Egypt, Arab congressmen against corruption, December 2007.

- UNDP, Re-conceptualizing Governance, Discussion Paper 2, New York: UNDP, 1997.

- UNDP, Institutional Arrangements to Combat Corruption: A Comparative Study, UNDP Regional Centre: Thailand, 2005.

- UNDP, Mainstreaming Anti-Corruption in Development, UNDP: New York, 2008.

- UNESCAP, What is Good Governance?
www.unescap.org/pdd/prs/ProjectActivities/Ongoing/gg/governance.asp (accessed 22 October 2011).

- Vian T, Brinkerhoff DW, Feeley FG, Salomon M, Vien NTK, Health sector corruption in Vietnam, Public Administration and Development, vol. 32, 2012. 


\section{Macrothink}

Journal of Public Administration and Governance ISSN 2161-7104 2013, Vol. 3, No. 4

- Werner Nicholas Webb, Ethical Culture and The Value-Based Approach To Integrity Management: A Case Study Of The Department Of Correctional Services, public administration and development review, vol. 32, 2012.

- Yassin, E. (ed.), Egyptian Bureaucracy, an Empirical Study, Cairo: Al Ahram Center for Political and Strategic Studies, 1994.

Anti- corruption national strategy (2008-2011), Jordanian kingdom.

-Hussein Mahmoud Hassan, An analytical study for corruption causes in Egypt before 25th January revolution: towards future vision to preclude this phenomenon, Social Contract Center, 2011.

-Tanzi, Vito, Corruption, Arm's-Length Relationships, and Markets in The Economics of Organized Crime, edited by Gianluca Fiorentini and Sam Peltzman, Cambridge University Press, 1995.

- Tanzi, Vito, Corruption around the World: Causes, Consequences, Scope, and Cures, International Monetary Fund working paper, May 1998.

-The first report for integrity and transparency, committee of Egyptian administrative development minister, 2007. 